\title{
Suppression of Wheat Growth and Yield by Pratylenchus neglectus in the Pacific Northwest
}

Richard W. Smiley, Professor, and Ruth G. Whittaker, Jennifer A. Gourlie, and Sandra A. Easley, Faculty Research Assistants, Oregon State University, Columbia Basin Agricultural Research Center, P.O. Box 370, Pendleton 97801

\begin{abstract}
Smiley, R. W., Whittaker, R. G., Gourlie, J. A., and Easley, S. A. 2005. Suppression of wheat growth and yield by Pratylenchus neglectus in the Pacific Northwest. Plant Dis. 89:958-968.

Many wheat (Triticum aestivum) fields planted annually in the Pacific Northwest are infested by high populations of the lesion nematode, Pratylenchus neglectus. Spring wheat cultivars varying in tolerance and resistance to $P$. neglectus were treated or not treated with aldicarb to examine relationships between the nematode and growth and yield of annual direct-seeded (no-till) wheat. Increasing initial density of P. neglectus in soil was more strongly associated with declining growth and yield of intolerant (Machete and Spear) than moderately tolerant (Frame and Krichauff) cultivars. Yield suppression by $P$. neglectus was generally 8 to $36 \%$ for intolerant cultivars, but reached $71 \%$ in soil also harboring Heterodera avenae, Rhizoctonia solani AG-8, and Gaeumannomyces graminis var. tritici. Intolerant cultivars had lower yields than Krichauff in rainfed but not in irrigated experiments. Density of $P$. neglectus in mature roots was generally lower for moderately resistant Krichauff than for susceptible Machete and Spear. Aldicarb improved yields in irrigated but not in rainfed experiments, and increased plant height and reduced variability in tiller height, canopy temperature, and density of $P$. neglectus in roots. This is the first report of damage to wheat by $P$. neglectus in the Pacific Northwest. Breeding wheat for tolerance and resistance to $P$. neglectus is suggested.
\end{abstract}

Additional keywords: Fusarium crown rot, Fusarium pseudograminearum, Pratylenchus thornei, Pythium root rot, Pythium spp., Rhizoctonia root rot, take-all

Conservation farming systems are becoming more widely practiced in semiarid regions of the Pacific Northwest states of Oregon and Washington. Most rainfed (dryland) wheat (Triticum aestivum L.) in the region has traditionally been produced as a 2-year rotation of winter wheat and summer fallow. This low-frequency rotation is the most profitable production system for rainfed fields that receive 250 to $400 \mathrm{~mm}$ of annual precipitation, with little rain during the summer. Many wheatfallow rotations are vulnerable to water erosion, and also contribute to concerns regarding quality of air and water. Interest in conservation tillage systems (4) has led to conversion of land formerly in winter wheat-summer fallow rotation to spring wheat or barley planted annually without tillage. Approximately $20 \%$ of dryland spring grains in Oregon and Washington are now planted without tillage, with percentages of 20 to $40 \%$ in at least four major cereal-producing counties (35). Most direct-seeded dryland fields are planted

Corresponding author: R. W. Smiley

E-mail: richard.smiley@ oregonstate.edu

Accepted for publication 29 April 2005.

DOI: 10.1094/PD-89-0958

(C) 2005 The American Phytopathological Society annually to cereals because this is more profitable than rotation with other crop species. Wheat is also produced with supplemental irrigation, usually in long rotations with higher-value crops. However, economic considerations in some regions cause growers to produce irrigated wheat annually.

Populations of the lesion nematode Pratylenchus neglectus (Rensch, 1924) Filipjev Schuurmanns \& Stekhoven, 1941 may increase dramatically when dryland fields are shifted to a higher intensity of cereal cropping (12). Direct associations between Pratylenchus spp. populations and frequency of cereal cropping have been reported (27), and populations are generally much lower following summer fallow than after wheat (22). Populations of P. thornei Sher \& Allen, 1953 can be reduced to nondamaging levels if wheat is grown no more frequently than once every 3 years in rotation with crops less suitable for multiplication of the nematode (3). Greater populations of $P$. thornei and $P$. neglectus have been detected in annually cropped fields than in winter wheat-summer fallow rotations in the $\mathrm{Pa}$ cific Northwest wheat belt (34).

$P$. neglectus causes economic damage to barley in North America (10) and to wheat in Australia, where preplant populations have been negatively correlated with wheat yield $(41,44)$. However, damage relationships between $P$. neglectus population and wheat yield differ among sites and growing seasons. Yield constraint from root damage depends on the nematode species and numbers in roots; crop species, cultivar, growth stage, and rotation; tillage management; and soil temperature, moisture, and texture. Although high populations of Pratylenchus spp. have been reported in annually cropped fields in the Pacific Northwest (34), it is recognized that nematode population estimates are often poor predictors of potential damage (27).

In the Pacific Northwest, $P$. neglectus was reported as a weak parasite of winter wheat cv. Stephens on the basis of slightly reduced foliar growth in a greenhouse seedling assay (19). This plant-parasitic species was subsequently associated with reduction of winter wheat yield under field conditions (34). While the importance of $P$. neglectus on spring wheat has not been examined in the Pacific Northwest, Smiley et al. (36) reported that high populations of $P$. thornei were negatively associated with plant growth, grain yield, and grain quality for annually cropped $P$. thornei-intolerant spring wheat cultivars. Moreover, as the population of $P$. thornei increased, yield stability was often more favorable for moderately tolerant than for intolerant wheat cultivars.

This paper reports the relationships between $P$. neglectus and yield for dryland and irrigated annual no-till spring wheat in eastern Oregon. Procedures and wheat germ plasm were selected to provide direct comparisons with research on $P$. neglectus in Australia $(41,44)$, and with parallel research on $P$. thornei in the Pacific Northwest (36).

\section{MATERIALS AND METHODS}

Locations, climates, and crop management. Five field experiments were performed during 2003 at three locations in northeastern Oregon. Experiments were performed on the Cuthbert farm, $10 \mathrm{~km}$ northeast of LaGrande, the Davis farm, 13 $\mathrm{km}$ east-southeast of LaGrande, and the Oregon State University Columbia Basin Agricultural Research Center, 1 km southeast of Moro. Annual precipitation averages 480, 395, and $282 \mathrm{~mm}$ at the Cuthbert farm, Davis farm, and Moro, respectively. Average daily air temperature is $-1{ }^{\circ} \mathrm{C}$ during January and $19^{\circ} \mathrm{C}$ during July and August at each location. Soils were an Imbler fine sandy loam at the Cuthbert 
farm, Hoopal fine sandy loam at the Davis farm, and Walla Walla silt loam at Moro. Each soil was deep and well-drained. Two adjacent experiments were performed at the Davis farm and at Moro, and are distinguished as Moro-1 and Moro-2, and Davis-1 and Davis-2. Each field had a recent history of annual cropping without tillage, had been planted to wheat the preceding year, and was naturally infested with $P$. neglectus. Wheat received supplemental irrigation until the soft-dough stage at the Cuthbert farm, to physiological maturity at the Davis farm, and was not irrigated at Moro.

Spring wheat was planted as a directseed (no-till) annual crop at each location. Experiments were planted at the Cuthbert and Davis farms on 14 April and at Moro on 10 April. Seed was planted using a drill equipped with a cone-seeder and four openers at $36-\mathrm{cm}$ row spacing. Fertilizer was applied by banding below the seed at the time of planting. Fertilizer and herbicide applications were uniform across each experimental area, and were consistent with standard practices. Wheat seed was treated with fungicides (tebuconazole plus mefenoxam) to suppress seed rot and seedling damping-off.

Wheat cultivars included Frame, Krichauff, Machete, and Spear, each of which is an Australian cultivar characterized by tolerance as well as resistance to $P$. neglectus $(40,44,48)$. Tolerance is defined as the ability of the plant to withstand nematode infection (28), and is generally measured as the ability of the plant to maintain yield potential in the presence of moderate to high populations of plantparasitic nematodes. Resistance is defined as the ability of the plant to suppress development or reproduction of the nematode (28), and is measured either as final nematode density in roots or soil, or as a multiplication factor consisting of final population (Pf) divided by initial population $(\mathrm{Pi})$ in soil. Reactions to $P$. neglectus by Machete and Spear have been characterized $(40,44,48)$ as moderately intolerant to intolerant, and susceptible to very susceptible. Reactions of Frame have been characterized as moderately intolerant to tolerant, and moderately susceptible to susceptible. Reactions of Krichauff have been characterized as moderately intolerant to tolerant, and moderately resistant to moderately susceptible. Frame and Spear were planted in the Cuthbert farm and Davis-1 experiments, Krichauff and Machete were planted in the Moro-1 and Davis-2 experiments, and Krichauff and Spear were planted in the Moro-2 experiment.

Aldicarb (Temik 15G) was mixed with the seed in the seed cone while planting half of the plots in each experiment. Aldicarb was dispensed at $4.2 \mathrm{~kg}$ a.i./ha to suppress damage and reproduction by Pratylenchus spp. (41).
The experimental design at each location was a two-way randomized complete block with variables of wheat cultivar and aldicarb treatment in $1.7 \times 6.1 \mathrm{~m}$ plots. Each treatment (two cultivars, with and without aldicarb) at each location was replicated nine times, for a total of 36 plots. Locations of experiments were marked by burying woven-wire cables vertically into the four corners of each experimental area.

The Moro-1 experiment was replanted uniformly to the Pacific Northwestadapted spring wheat cv. Zak during March 2004 using a commercial directseed drill and standard production practices. Plots were harvested in August, and yields were compared to $P$. neglectus populations prior to planting; the Pf values were determined for the study performed during 2003.

Soil sampling and nematode extraction. Soil was collected to assess Pratylenchus spp. populations in individual plots for all experiments. Initial samples (Pi) were collected while soil was moist during early April 2003, 2 days prior to planting. Samples consisted of 15 to 20 cores (2.5 $\mathrm{cm}$ diameter $\times 10 \mathrm{~cm}$ deep) composited for each $10 \mathrm{~m}^{2}$ plot. Final soil samples (Pf) were collected during late February 2004 to evaluate residual influences, if any, of the cultivar and aldicarb treatments applied during 2003. The Pf sampling was deferred until spring (February) because soils were dry and hard following harvest, which is known to cause a significant underestimate of Pratylenchus spp. density in soil (39). To account for vertical distribution of Pratylenchus $(39,42)$, the 2004 samples were collected to a depth of $20 \mathrm{~cm}$. Samples were stored moist at $4{ }^{\circ} \mathrm{C}$ for up to 7 days before being transported to a commercial diagnostic laboratory (Western Laboratories, Parma, ID) for extraction and identification of nematodes. Multiplication factors (Pf/Pi) were calculated for P. neglectus in each plot, except at the Cuthbert farm, where farming practices prevented sampling during 2004.

A modified elutriation method (16) was used to extract all soil-dwelling nematodes from 250 -g subsamples. Using an Oosterbrink elutriator, coarse material was collected on a $500-\mu \mathrm{m}$ sieve, cysts on a 125 $\mu \mathrm{m}$ sieve, and free-living nematodes on a stack of two $38-\mu \mathrm{m}$ and two $32-\mu \mathrm{m}$ sieves. Free-living nematodes were washed into $100-\mathrm{ml}$ cups. Cysts were ground to release eggs and larvae, and were added to the 100-ml cups. Suspensions were stored overnight, and settled nematodes were transferred to 50-ml centrifuge tubes and concentrated by 3,200 rpm for $5 \mathrm{~min}$. Water was discarded, replaced by magnesium sulfate solution at specific gravity 1.80 , mixed by spatula, and centrifuged again for $4 \mathrm{~min}$. The supernatant solution containing nematodes was passed over a 20$\mu \mathrm{m}$ sieve, transferred to another $50-\mathrm{ml}$ tube, and allowed to settle for at least $2 \mathrm{~h}$ before counting.

Enumeration of nematodes was performed by reducing the volume of suspension in the $50-\mathrm{ml}$ tubes to $10 \mathrm{ml}$, mixing the remaining suspension in a mini-vortex mixer for $5 \mathrm{~s}$, removing $4 \mathrm{ml}$ of suspension, placing $1 \mathrm{ml}$ on a Peter's counting slide, and counting and identifying all plant-parasitic nematode genera on the slide. Pratylenchus was identified to genus level based on standard morphological characteristics and measurements $(11,14)$. Numbers are reported as nematodes per kilogram of oven-dry soil.

Pratylenchus spp. extracted from each experiment were further identified to species using DNA profiles in a composite of extractions from each plot. During 2003, a subsample of the composite was dried and sent to the Root Disease Testing Service in Adelaide, South Australia, where P. neglectus and $P$. thornei were each identified and quantified from extracted DNA (24). Results, in picograms of DNA per gram of soil, were converted through calibrations into estimates for numbers of each Pratylenchus species per kilogram of soil. The numerical estimates were used to determine proportions of each species in each experimental area. During 2004, Pratylenchus spp. were identified in our laboratory using procedures described by Waeyenberge et al. (47). Extracts returned from Western Laboratories were used to extract DNA from plots with high numbers of Pratylenchus spp. Results of DNA analyses in our laboratory were based on intensity, or presence versus absence, of banding patterns for each Pratylenchus spp., but these tests have not been calibrated with numbers of Pratylenchus spp. in soil in Oregon.

Plant sampling, nematode extraction, and disease assessment. Root systems from 20 plants were collected from each plot in June, between anthesis and grain filling. Roots to $10-\mathrm{cm}$ depth were collected for five plants at each of four subsampling sites in each plot. Whole plants were stored at $4^{\circ} \mathrm{C}$ before being sent to Western Laboratories. Endoparasitic nematodes were extracted using a standard 7-day root-mist procedure (16), with samples misted for 60 s every $5 \mathrm{~min}$. Nematodes were counted and identified as described for soil extracts. Numbers for each species were normalized to equal units of root mass and reported as nematodes per gram of fresh root tissue and of oven-dry root tissue.

A separate group of plants was also collected to assess incidence and severity of diseases caused by soilborne plantpathogenic fungi, and to measure plant height and growth stage. Because there were no treatment effects in comparable experiments during 2001 and 2002 (unreported data), diseases were assessed only on 25 plants with intact roots to $10-\mathrm{cm}$ depth collected arbitrarily across each 
experimental area during June 2003 (heading stage). Roots were scored visually for incidence and severity of disease (33). Plant height was also measured on 25 plants from each plot and, for the Davis-2 experiment, the Haun plant growth stage (5) was also measured.

Other plant growth and development data were as follows. Seedling emergence was measured 1 month after planting. Leaf canopy temperature at the soft-dough stage was measured as an indicator of the plant water stress differential between aldicarbtreated and control plots $(8,21)$ during mid-afternoon on hot days in July, using a Raynger ST noncontact thermometer (Raytek Corp., Santa Cruz, CA). Plant height, variability in head height, and density of headed tillers were measured immediately before harvest. Variability in head height was calculated by dividing the standard deviation by mean head height. Plots were harvested with an experimental plot combine to measure grain yield, test weight, and kernel weight.

Statistical analysis. Nematode populations were described by calculating means and standard deviations among plots. All plant growth, disease, and nematode variables among cultivar $\times$ aldicarb treatment combinations were analyzed by analysis of variance for the two-way randomized complete block model, using Co-Stat Statistical Software version 6.101 (CoHort Software, Monterey, CA). When treatment effects were significant at $P<0.05$, means were separated using the least significant difference test (LSD). Variables were also evaluated by regression analysis using a linear model.

\section{RESULTS}

Populations and identities of Pratylenchus spp. in soil. Initial populations of

Table 1. Densities of the Pratylenchus populations in soil samples ${ }^{\text {a }}$ collected before planting spring wheat into five experiments at three locations in Oregon

\begin{tabular}{lccccr}
\hline \multirow{2}{*}{$\begin{array}{l}\text { Irrigation } \\
\text { Location }^{\mathbf{b}}\end{array}$} & & & \multicolumn{3}{c}{ Pratylenchus spp./kg soil } \\
\cline { 5 - 6 } & Year & Species $^{\mathbf{c}}$ & Mean & Range & SD \\
\hline Nonirrigated & & & & & \\
Moro-1 & 2003 & $\mathrm{Pn}$ & 1,538 & $140-4,120$ & 1,126 \\
& 2004 & $\mathrm{Pn}$ & 1,513 & $180-4,300$ & 979 \\
Moro-2 & 2003 & $\mathrm{Pn} / \mathrm{Pt}$ & 989 & $140-3,440$ & 678 \\
& 2004 & $\mathrm{Pn} / \mathrm{Pt}$ & 1,588 & $260-4,160$ & 1,002 \\
Irrigated & & & & & \\
Cuthbert & 2003 & $\mathrm{Pn}$ & 2,556 & $0-15,300$ & 2,248 \\
Davis-1 & 2003 & $\mathrm{Pn}$ & 3,217 & $1,540-5,440$ & 910 \\
& 2004 & $\mathrm{Pn}$ & 868 & $0-2,540$ & 724 \\
Davis-2 & 2003 & $\mathrm{Pn}$ & 4,601 & $1,900-11,520$ & 2,012 \\
& 2004 & $\mathrm{Pn}$ & 1,618 & $0-14,440$ & 2,572 \\
\hline
\end{tabular}

${ }^{\text {a }}$ Samples for each experiment were composed of 15 to 20 soil cores composited for each of 36 plots arranged in adjacent blocks of 12 columns $\times 3$ rows.

${ }^{\mathrm{b}}$ Two experiments were at Moro and Davis; sites are differentiated as 1 or 2 for each location; example: Moro-1 or Moro-2.

${ }^{c}$ Pratylenchus species: $\mathrm{Pn}=P$. neglectus, $\mathrm{Pt}=P$. thornei, and $\mathrm{Pn} / \mathrm{Pt}=$ species mixtures and order of decreasing proportions.
Pratylenchus spp. were highly variable among the 36 plots in each experiment (Table 1). DNA extracts in Australia during 2003 indicated a strong dominance of $P$. neglectus over $P$. thornei at Moro-1 (9,000 versus $<1,000$ nematodes/kg soil), Moro-2 (4,000 versus 1,000 nematodes $/ \mathrm{kg}$ soil), Cuthbert farm $(6,000$ versus $<1,000$ nematodes $/ \mathrm{kg}$ soil), and Davis farm (6,000 versus $<1,000$ nematodes $/ \mathrm{kg}$ soil). The lower detection limit was 1,000 nematodes $/ \mathrm{kg}$, indicating the possibility that populations were entirely $P$. neglectus in experiments at Moro-1 and the Cuthbert and Davis farms. DNA analyses at our laboratory during 2004 also indicated a strong presence of $P$. neglectus and an inability to detect $P$. thornei at all three locations.

Replication and randomization of treatments minimized the impact of high spatial heterogeneity within experiments, as indicated by an absence of difference $(P<$ 0.05 ) in initial Pratylenchus populations among treatments subsequently planted to cultivar and aldicarb variables during 2003 (Table 2). Final Pratylenchus populations during 2004 were significantly $(P<0.05)$ lower than in 2003 at the Davis-1 and Davis-2 experiments, in response to significantly $(P<0.05)$ lower populations in aldicarb-treated compared to control plots (Table 2). During 2004, a residual influence from the cultivar variable occurred at the Moro-1 and Davis-2 experiments, where the Pratylenchus population was lower following Krichauff than Machete. Also during 2004, a cultivar by aldicarb interaction was significant (Table 2), indicating that the suppressive influence of aldicarb on $P$. neglectus population was greater for Machete than for Krichauff.

The multiplication factor $(\mathrm{Pf} / \mathrm{Pi})$ for $P$. neglectus was unaffected by cultivar or aldicarb treatments in two dryland experi-

Table 2. Populations of Pratylenchus spp. in soil during early spring for five experiments at three Oregon locations during 2003 and 2004; samples during 2004 reflect residual influences from the designated cultivar $\times$ aldicarb variables examined the previous year

\begin{tabular}{|c|c|c|c|c|c|c|c|c|c|}
\hline \multirow{2}{*}{$\begin{array}{c}\text { Irrigation } \\
\text { Location }^{\text {a }} \\
\end{array}$} & \multirow[b]{2}{*}{ Year $^{\mathbf{b}}$} & \multirow[b]{2}{*}{ Cultivars $^{\mathrm{c}}$} & \multicolumn{2}{|c|}{$\begin{array}{c}\text { Least susceptible cultivar: } \\
\text { K or } \mathbf{F}^{\mathrm{c}}\end{array}$} & \multicolumn{2}{|c|}{$\begin{array}{c}\text { Most susceptible cultivar: } \\
\text { M or } \mathbf{S}^{\mathbf{c}} \\
\end{array}$} & \multicolumn{3}{|c|}{ Significance $^{\mathrm{d}}(P>F)$} \\
\hline & & & Control & Aldicarb & Control & Aldicarb & Cultivar & Aldicarb & Cult. $\times$ ald \\
\hline \multicolumn{10}{|l|}{ Nonirrigated } \\
\hline \multirow[t]{2}{*}{ Moro-1 } & 2003 & $\mathrm{~K}, \mathrm{M}$ & 1,351 & 1,260 & 1,996 & 1,549 & 0.26 & 0.51 & 0.66 \\
\hline & 2004 & & 1,349 & 938 & 1,860 & 1,909 & $<0.01 * *$ & 0.49 & 0.39 \\
\hline \multirow[t]{2}{*}{ Moro-2 } & 2003 & $\mathrm{~K}, \mathrm{~S}$ & 1,078 & 1,016 & 1,067 & 798 & 0.60 & 0.44 & 0.63 \\
\hline & 2004 & & 1,547 & 1,715 & 1,404 & 1,688 & 0.69 & 0.30 & 0.86 \\
\hline \multicolumn{10}{|l|}{ Irrigated } \\
\hline Cuthbert & 2003 & $\mathrm{~F}, \mathrm{~S}$ & 2,500 & 2,209 & 2,583 & 2,931 & 0.77 & 0.83 & 0.60 \\
\hline \multirow[t]{2}{*}{ Davis-1 } & 2003 & $\mathrm{~F}, \mathrm{~S}$ & 3,502 & 3,640 & 3,140 & 2,587 & 0.57 & 0.12 & 0.78 \\
\hline & 2004 & & 1,569 & 157 & 1,493 & 253 & 0.83 & $<0.001 * * *$ & 0.99 \\
\hline \multirow[t]{2}{*}{ Davis-2 } & 2003 & $\mathrm{~K}, \mathrm{M}$ & 4,916 & 4,240 & 4,591 & 4,671 & 0.94 & 0.40 & 0.50 \\
\hline & 2004 & & 1,153 & 238 & 4,422 & 658 & $0.01 *$ & $<0.01 * *$ & $0.05^{*}$ \\
\hline
\end{tabular}

a Two experiments were at Moro and Davis; sites are differentiated as 1 or 2 for each location; example: Moro-1 or Moro-2.

${ }^{\mathrm{b}}$ Initial soil populations (Pi) were from samples collected prior to planting wheat during spring 2003. Final soil populations (Pf) were assessed 1 year later, during spring 2004, without soil disturbance over the Pi-to-Pf interval.

${ }^{\mathrm{c}}$ Cultivars varied among experiments. With regard to reactions to P. neglectus in Australia, Krichauff (K) is moderately resistant to moderately susceptible, and tolerant to moderately intolerant; Frame $(\mathrm{F})$ is moderately susceptible to susceptible, and tolerant to moderately intolerant; and Machete (M) and Spear (S) are susceptible to very susceptible, and moderately intolerant to intolerant. In this table, Krichauff and Frame are grouped as "less susceptible/more tolerant" cultivars, and Machete and Spear are grouped as "more susceptible/less tolerant" cultivars.

${ }^{\mathrm{d}}$ Degrees of freedom for the 36-plot experimental design during 2003, and follow-up sampling during 2004, were nematicide (1), cultivar (1), nematicide $\times$ cultivar (1), error (25), total (35). Comparisons were accepted as significant at confidence intervals of $95 \%(*), 99 \%(* *)$, or $99.9 \%$ (***). 
ments at Moro (Table 3). The multiplication factor was lower $(P<0.001)$ for Krichauff than for Machete in the Davis-2 experiment, and was lower in aldicarb than control treatments for both cultivars. A significant $(P<0.001)$ cultivar $\times$ aldicarb interaction at the Davis-2 experiment indicated a greater influence of aldicarb on the multiplication rate for $P$. neglectus in $\mathrm{Ma}-$ chete than in Krichauff. For the Davis-1 experiment, multiplication rates did not differ between Frame and Spear but were lower $(P<0.001)$ in aldicarb than in control plots. Overall, the multiplication factors for $P$. neglectus were lower $(P<$ $0.001)$ for the two irrigated experiments at the Davis farm than for the two dryland experiments at Moro.

Pratylenchus density in roots. The density of $P$. neglectus in mature roots differed $(P<0.01)$ between cultivars in two of five experiments (Table 4). In control plots, the density differed significantly in each of the three experiments in which Krichauff was compared with either Machete or Spear. Densities of P. neglectus were always higher in Machete and Spear than in Krichauff. Densities of P. neglectus in control plots did not differ between Frame and Spear at the Cuthbert farm and Davis-1 experiment. Aldicarb treatment significantly reduced $P$. neglectus density in roots in all experiments. Significant cultivar $\times$ aldicarb interactions occurred in two experiments.

The density of $P$. neglectus in mature roots was correlated $\left(P=0.005, r^{2}=0.40\right)$ with the initial population of $P$. neglectus in soil at the Davis-1 experiment, and with the final soil population of $P$. neglectus ( $P$ $\left.<0.0001, r^{2}=0.79\right)$ at the Davis-2 experiment.

Relative $P$. neglectus densities were comparable when evaluated on the basis of either fresh- or dry-root weights during 2003. Densities of $P$. neglectus in roots averaged 5.2 times higher when reported on dry weight rather than the fresh-weight basis reported in Table 4.

Other plant-parasitic nematodes in soil. Tylenchorhynchus clarus Allen, 1955, Heterodera avenae Wollenweber, 1924, and an unidentified species of Meloidogyne were present in fields at Moro (data not presented). Population means for each treatment were never higher than 4 nematodes $/ \mathrm{kg}$ (range of 0 to 50 in individual plots) for $T$. clarus, 1 nematode $/ \mathrm{kg}$ (range of 0 to 20) for $H$. avenae, and 2 nematodes $/ \mathrm{kg}$ (range of 0 to 30) for Meloidogyne.

Plant-parasitic nematodes at the Cuthbert and Davis farms included Criconemoides spp., Geocenamus brevidens (Allen, 1955) Brzeski, 1991, H. avenae, T. clarus, Meloidogyne naasi Franklin, and Paratylenchus spp. The stunt nematode $G$. brevidens was present at a population density of 1 nematode $/ \mathrm{kg}$ soil at the Cuthbert farm. Populations in the Tylenchorhynchus/Geocenamus complex in both experiments at the Davis farm during 2003 averaged 25 nematodes $/ \mathrm{kg}$ soil (range of 0 to 180), but genera and species were not determined. Mean populations of $M$. naasi were 44 nematodes $/ \mathrm{kg}$ soil (range of 0 to 490) at the Cuthbert farm and 148 per kg soil (range of 0 to 2,920) at the Davis-1 experiment. Criconemoides spp. occurred at very low densities (1 nematode/kg; range of 0 to 20) at each location, and Paratylenchus spp. densities were highly variable (means up to 21,076 nematodes $/ \mathrm{kg}$; range of 260 to 55,780 ).

Table 3. Multiplication factors $(\mathrm{Pf} / \mathrm{Pi})^{\mathrm{a}}$ for Pratylenchus neglectus in response to cultivar and aldicarb variables for five experiments in Oregon during 2003

\begin{tabular}{|c|c|c|c|c|c|c|c|c|}
\hline \multirow[b]{2}{*}{ Location $^{b}$} & \multirow[b]{2}{*}{ Cultivars $^{\mathrm{c}}$} & \multicolumn{2}{|c|}{$\begin{array}{c}\text { Least susceptible cultivar: } \\
\text { K or } \mathbf{F}^{c}\end{array}$} & \multicolumn{2}{|c|}{$\begin{array}{c}\text { Most susceptible cultivar: } \\
\text { M or } \mathbf{S}^{\mathbf{c}} \\
\end{array}$} & \multicolumn{3}{|c|}{ Significance $^{\mathrm{d}}(P>\mathrm{F})$} \\
\hline & & Control & Aldicarb & Control & Aldicarb & Cultivar & Aldicarb & Cult. $\times$ ald. \\
\hline Moro-1 & $\mathrm{K}, \mathrm{M}$ & 1.00 & 0.74 & 0.93 & 1.23 & 0.81 & 0.77 & 0.08 \\
\hline Moro-2 & $\mathrm{K}, \mathrm{S}$ & 1.44 & 1.69 & 1.32 & 2.12 & 0.47 & 0.24 & 0.35 \\
\hline Davis-1 & $\mathrm{F}, \mathrm{S}$ & 0.44 & 0.04 & 0.48 & 0.10 & 0.27 & $<0.001 * * *$ & 0.54 \\
\hline Davis-2 & $\mathrm{K}, \mathrm{M}$ & 0.23 & 0.06 & 0.96 & 0.14 & $<0.001 * * *$ & $<0.001 * * *$ & $<0.001 * * *$ \\
\hline
\end{tabular}

${ }^{a}$ Multiplication factor was derived from the number of nematodes/kg soil before planting and application of aldicarb during April 2003 (Pi), and resampling 1 year later (Pf). Plots were not tilled or cropped between harvest (August 2003) and collection of Pf samples during March 2004.

${ }^{b}$ Experiments at the Davis farm received supplemental irrigation. Experiments were entirely rainfed at the Columbia Basin Agricultural Research Center at Moro. Two experiments were at Moro and Davis; sites are differentiated as 1 or 2 for each location; example: Moro-1 or Moro-2.

${ }^{c}$ Cultivars varied among experiments. With regard to reactions to P. neglectus in Australia, Krichauff $(\mathrm{K})$ is moderately resistant to moderately susceptible, and tolerant to moderately intolerant; Frame (F) is moderately susceptible to susceptible, and tolerant to moderately intolerant; and Machete (M) and Spear (S) are susceptible to very susceptible, and moderately intolerant to intolerant. In this table, Krichauff and Frame are grouped as "less susceptible/more tolerant" cultivars, and Machete and Spear are grouped as "more susceptible/less tolerant" cultivars.

${ }^{\mathrm{d}}$ Degrees of freedom for the 36-plot experimental design were nematicide (1), cultivar (1), nematicide $\times$ cultivar (1), error (25), total (35). Comparisons were accepted as significant at confidence intervals of $95 \%(*), 99 \%(* *)$, or $99.9 \%(* * *)$.

Table 4. Density of Pratylenchus spp. in mature roots ${ }^{\mathrm{a}}$ in aldicarb-treated and untreated plantings of spring wheat in five experiments at three Oregon locations during 2003

\begin{tabular}{|c|c|c|c|c|c|c|c|c|}
\hline \multirow{2}{*}{$\begin{array}{c}\text { Irrigation } \\
\text { Location }^{\mathbf{b}} \\
\end{array}$} & \multirow[b]{2}{*}{ Cultivars $^{\mathrm{c}}$} & \multicolumn{2}{|c|}{$\begin{array}{l}\text { Least susceptible, most } \\
\text { tolerant cultivar: } K \text { or } F^{c}\end{array}$} & \multicolumn{2}{|c|}{$\begin{array}{c}\text { Most susceptible, least } \\
\text { tolerant cultivar: } M \text { or } S^{c}\end{array}$} & \multicolumn{3}{|c|}{ Significance $^{\mathrm{d}}(P>F)$} \\
\hline & & Control & Aldicarb & Control & Aldicarb & Cultivar & Aldicarb & Cult. $\times$ ald. \\
\hline \multicolumn{9}{|l|}{ Nonirrigated } \\
\hline Moro-1 & $\mathrm{K}, \mathrm{M}$ & 1,578 & 54 & 6,041 & 27 & 0.12 & $0.01 * *$ & 0.11 \\
\hline Moro-2 & $\mathrm{K}, \mathrm{S}$ & 217 & 14 & 752 & 11 & $<0.01 * *$ & $<0.01 * * *$ & $<0.01 * *$ \\
\hline \multicolumn{9}{|l|}{ Irrigated } \\
\hline Cuthbert & $\mathrm{F}, \mathrm{S}$ & 192 & 13 & 337 & 10 & 0.16 & $<0.01 * * *$ & 0.76 \\
\hline Davis-1 & $\mathrm{F}, \mathrm{S}$ & 354 & 21 & 627 & 97 & 0.14 & $<0.01 * * *$ & 0.40 \\
\hline Davis-2 & $\mathrm{K}, \mathrm{M}$ & 294 & 3 & 2,392 & 20 & $0.01 * *$ & $<0.01 * * *$ & $<0.01 * * *$ \\
\hline \multirow{2}{*}{\multicolumn{9}{|c|}{$\begin{array}{l}\text { a Pratylenchus spp. density is reported as numbers of nematodes/g fresh root tissue. Multiply the data by } 5.2 \text { to estimate numbers of nematodes/g dry roo } \\
\text { tissue. } \\
\text { b Two experiments were at Moro and Davis; sites are differentiated as } 1 \text { or } 2 \text { for each location; example: Moro- } 1 \text { or Moro- } 2 \text {. }\end{array}$}} \\
\hline & & & & & & & & \\
\hline \multicolumn{9}{|c|}{$\begin{array}{l}\text { " Cultivars varied among experiments. With regard to reactions to P. neglectus in Australia, Krichauff (K) is moderately resistant to moderately susceptible, } \\
\text { and tolerant to moderately intolerant; Frame (F) is moderately susceptible to susceptible, and tolerant to moderately intolerant; and Machete (M) and Spear } \\
\text { (S) are susceptible to very susceptible, and moderately intolerant to intolerant. In this table, Krichauff and Frame are grouped as "less susceptible/more } \\
\text { tolerant" cultivars, and Machete and Spear are grouped as "more susceptible/less tolerant" cultivars. }\end{array}$} \\
\hline${ }^{d}$ Degrees of $\mathrm{f}$ & $\begin{array}{l}\text { for the } 3 \\
\text { ant at con }\end{array}$ & $\begin{array}{l}\text { xperimen } \\
\text { intervals }\end{array}$ & Do & P & , nematicid & tivar (1), er & 5), total (35 & mparisons were \\
\hline
\end{tabular}


Populations of $H$. avenae were low at the Cuthbert farm and high at the Davis farm. Hatched juveniles were not detected at either location at the time of planting during 2003. Initial densities of eggs plus juveniles released from extracted cysts were 7 nematodes $/ \mathrm{kg}$ (range of 0 to 160) at the Cuthbert farm. Initial densities for $H$. avenae at the Davis-1 experiment were 1,690 nematodes $/ \mathrm{kg}$ (range of 100 to $8,020)$ during 2003 and 1,279 nematodes $/ \mathrm{kg}$ (range of 0 to 4,400) during 2004, and at the Davis-2 experiment were 784 nematodes $/ \mathrm{kg}$ (range of 160 to 2,060) during 2003 and 2,070 nematodes/kg (range of 0 to 16,780) during 2004.

At the Davis farm, 1 month after harvest during 2003, a supplemental sampling was performed to determine effects of treatments on populations of $H$. avenae eggs and juveniles from cysts. When compared with initial populations, the multiplication factor $(\mathrm{Pf} / \mathrm{Pi})$ was lower $(P$ $<0.05)$ in the aldicarb than control treatment in the Davis-2 experiment, and did not differ between cultivars in either experiment. In the Davis-2 experiment, the multiplication factors were 8.7 and 0.5 for aldicarb and control treatments, respectively $\left(\mathrm{LSD}_{0.05}=3.0\right)$.

Disease symptoms and associations with nematodes. Disease symptoms during 2003 were caused by a complex of soilborne root-infecting fungal pathogens including Rhizoctonia solani Kühn AG-8 and $R$. oryzae Ryker \& Gooch (Rhizoctonia root rot), Gaeumannomyces graminis (Sacc.) Arx \& D. Olivier var. tritici J. Walker (take-all), Fusarium pseudograminearum O'Donnell \& T. Aoki (crown rot), and unidentified species of Pythium (Pythium root rot). One or more of these diseases generally occurred together with parasitism by nematodes. Visual estimates of disease incidence (percent plants with symptoms) and severity ( 0 to 4 scale; $0=$ none, $4=$ severe) were made for take-all, crown rot, and a "browning" root rot complex consisting of Rhizoctonia root rot, Pythium root rot, and lesion nematode.
Foliar diseases either did not occur or were of no importance in these experiments.

At the dryland sites, take-all was present at low to moderate severity (0.9 to 1.7$)$, variable incidence (19 to $92 \%$ ), and had no significant relationship $(P<0.05)$ with cultivar or aldicarb treatments. Browning root rot symptoms were also relatively minor, with low to moderate severity (1.0 to 2.2 ), variable incidence (8 to $92 \%$ ), and no association with treatments.

At irrigated sites, take-all and browning root rot were of minor severity ( 0.4 to 0.5 ) and incidence (24 to $29 \%$ ) at the Cuthbert farm, and of moderate severity (1.5 to 1.7 ) and high incidence (95 to $100 \%$ ) at the Davis-1 experiment. Concise browncolored lesions and spear-tip type root termini, typical of Rhizoctonia root rot, were of minor severity (0.2) and incidence $(24 \%)$ at the Cuthbert farm, and were of yield-limiting severity (2.8) and incidence $(100 \%)$ at the Davis-1 experiment. At both locations, Fusarium crown rot symptoms on subcrown internodes were present at very low severity $(<0.2)$ and incidence (<10\%). Witches'-brooms caused by $H$. avenae at the Cuthbert farm were of low severity (0.2) and incidence (16\%), and were more prevalent at the Davis-1 experiment, with mean severity of 1.8 on $72 \%$ of plants.

Severity of the browning root-rot complex at the Davis-1 experiment was positively associated with initial population of $P$. neglectus in soil $\left(P=0.003, r^{2}=0.44\right)$ and density of $P$. neglectus in roots $(P=$ $\left.0.06, r^{2}=0.21\right)$. Severity of take-all was negatively associated with severity of the browning root rot complex $\left(P<0.0001, r^{2}\right.$ $=0.82$ ).

At the Davis-2 experiment, Rhizoctonia root rot was more severe in aldicarbtreated than in control plots (ratings of 2.1 versus $1.4, \mathrm{LSD}_{0.05}=0.3$ ), and was more severe on Krichauff than Machete (ratings of 2.1 versus $1.5, \mathrm{LSD}_{0.05}=0.5$ ). Occurrences of witches'-brooms caused by $H$. avenae were lower in aldicarb-treated than in control plots (ratings of 0.1 versus 2.3,
$\mathrm{LSD}_{0.05}=0.3$ ), and did not differ among cultivars. Take-all severity ratings (1.0 to 2.8) did not differ significantly between cultivars or aldicarb treatments.

Plant growth and development. Seedling stand density was $10 \%$ lower $(P<$ $0.05)$ in aldicarb-treated than in control plots in three of five experiments: Davis-2, Moro-1, and Moro-2 (data not presented). Aldicarb treatment also reduced tillering for both cultivars in the Moro-2 experiment, where there were an average of 113 and 97 tillers $/ \mathrm{m}\left(\mathrm{LSD}_{0.05}=7\right)$ in control and aldicarb treatments, respectively. Density of headed tillers $(P<0.05)$ was slightly greater for Krichauff than for Machete at the Davis-2 experiment (data not presented).

Canopy leaf temperature was measured only for the irrigated experiments. Canopy temperature was reduced as much as $4^{\circ} \mathrm{C}$ by aldicarb treatment at the Cuthbert farm (41.6 versus $37.7^{\circ} \mathrm{C}, \mathrm{LSD}_{0.05}=1.9$ ), where irrigation had been terminated before crop maturation. Canopy temperature was 1 and $2{ }^{\circ} \mathrm{C}$ cooler (not significant at $P=0.05$ ) at the Davis-1 (30.9 versus $29.7^{\circ} \mathrm{C}, P=0.13$ ) and Davis-2 (39.9 versus $\left.37.9^{\circ} \mathrm{C}, P=0.26\right)$ experiments, where water continued to be applied until the wheat matured.

Aldicarb treatment increased $(P<$ 0.0001 ) plant height by 1 to $3 \mathrm{~cm}$ in three of five experiments: Moro-2, Davis-1, and Davis-2 (data not presented). The plant growth stage, measured as the Haun scale, was more advanced during mid-June in aldicarb-treated than in control plots (6.6 versus 6.2, $\mathrm{LSD}_{0.05}=0.3$ ) at the Davis-2 site, the only experiment where growth stage was measured.

Variability in plant height did not differ among cultivars in control plots (data not presented). Variability in plant height was reduced by aldicarb treatment in three of five experiments. This measure of aldicarb effect in control versus aldicarb-treated plots was 0.21 versus $0.20\left(\mathrm{LSD}_{0.05}=0.01\right)$ at Moro-2, 0.20 versus 0.18 LSD $_{0.05}=$ 0.01 ) at Davis-1, and 0.19 versus 0.16 $\left(\mathrm{LSD}_{0.05}=0.03\right)$ at Davis-2.

Table 5. Grain yield (kg/ha) for spring wheat grown in aldicarb-treated and untreated plots in five experiments at three Oregon locations during 2003

\begin{tabular}{|c|c|c|c|c|c|c|c|c|}
\hline \multirow{2}{*}{$\begin{array}{l}\text { Irrigation } \\
\text { Location }^{\mathrm{a}} \\
\end{array}$} & \multirow[b]{2}{*}{ Cultivars $^{\mathbf{b}}$} & \multicolumn{2}{|c|}{$\begin{array}{c}\text { Most tolerant cultivar: } \\
\mathbf{K} \text { or } \mathbf{F}^{\mathbf{b}} \\
\end{array}$} & \multicolumn{2}{|c|}{$\begin{array}{l}\text { Least tolerant cultivar: } \\
\qquad \text { or } S^{b}\end{array}$} & \multicolumn{3}{|c|}{ Significance $^{\mathrm{c}}(P>F)$} \\
\hline & & Control & Aldicarb & Control & Aldicarb & Cultivar & Aldicarb & Cult. $\times$ ald. \\
\hline \multicolumn{9}{|l|}{ Nonirrigated } \\
\hline Moro-1 & $\mathrm{K}, \mathrm{M}$ & 1,448 & 1,305 & 1,140 & 1,124 & $<0.01 * * *$ & $0.04 *$ & 0.14 \\
\hline Moro-2 & $\mathrm{K}, \mathrm{S}$ & 1,530 & 1,361 & 1,287 & 1,394 & $<0.01 * *$ & 0.40 & $<0.01 * * *$ \\
\hline \multicolumn{9}{|l|}{ Irrigated } \\
\hline Cuthbert & $\mathrm{F}, \mathrm{S}$ & 2,767 & 3,192 & 3,084 & 3,370 & 0.39 & $<0.01 * *$ & 0.33 \\
\hline Davis-1 & $\mathrm{F}, \mathrm{S}$ & 1,451 & 1,822 & 1,440 & 1,952 & 0.34 & $<0.01 * * *$ & 0.59 \\
\hline Davis-2 & $\mathrm{K}, \mathrm{M}$ & 1,502 & 2,110 & 1,601 & 1,924 & 0.61 & $<0.01 * * *$ & 0.19 \\
\hline
\end{tabular}

a Two experiments were at Moro and Davis; sites are differentiated as 1 or 2 for each location; example: Moro-1 or Moro-2.

${ }^{\mathrm{b}}$ Cultivars varied among experiments. With regard to reactions to P. neglectus in Australia, Krichauff (K) is moderately resistant to moderately susceptible, and tolerant to moderately intolerant; Frame (F) is moderately susceptible to susceptible, and tolerant to moderately intolerant; and Machete (M) and Spear (S) are susceptible to very susceptible, and moderately intolerant to intolerant. In this table, Krichauff and Frame are grouped as "less susceptible/more tolerant" cultivars, and Machete and Spear are grouped as "more susceptible/less tolerant" cultivars.

${ }^{c}$ Degrees of freedom for the 36-plot experimental design were nematicide (1), cultivar (1), nematicide $\times$ cultivar (1), error (25), total (35). Comparisons were accepted as significant at confidence intervals of $95 \%(*), 99 \%(* *)$, or $99.9 \%$ (***). 
Root weights in the upper $10 \mathrm{~cm}$ of soil were determined from samples used to extract endoparasitic nematode species. Fresh and dry root weights did not differ significantly for cultivar and aldicarb treatments in the three irrigated experiments: Cuthbert, Davis-1, and Davis-2. At Moro, dry root weights were higher $(P=$ 0.03 ) for Krichauff than for Spear in the Moro-2 experiment. Dry root weights were higher $(P=0.05)$ for aldicarb than for control treatments in both dryland experiments at Moro. Cultivar $\times$ aldicarb interactions did not differ significantly for root weights in any of the experiments.

Grain yield. Moderately tolerant cultivars yielded significantly more grain than intolerant cultivars for each of the nonirrigated experiments at Moro (Table 5). Cultivars did not differ in yield in the three irrigated experiments.

Aldicarb did not improve yields in the nonirrigated experiments and improved $(P$ $<0.01$ ) yield in each of the irrigated experiments (Table 5). Compared with aldicarb-treated plots in the irrigated experiments, yield suppression for individual cultivars in control plots ranged from 8 to $29 \%$. Averaged across cultivars, yield suppressions of 11,23 , and $23 \%$ were associ- ated with elevated populations of $P$. neglectus at the Cuthbert farm and the Davis1 and Davis-2 experiments, respectively. The proportional increase in yield due to aldicarb treatment was lower $(P<0.05)$ at the Cuthbert than in the Davis experiments. Irrigation at the Cuthbert farm was terminated at a time when the surrounding winter wheat crop became mature and the spring wheat in the experiment was in the early soft-dough stage. Spring wheat was watered to full maturation at the Davis farm. Aldicarb slightly reduced $(P<0.05)$ yield at the Moro-1 experiment, which was among the driest sites studied.

During 2004, at Moro-1, yield of Zak averaged 2,888 $\mathrm{kg} / \mathrm{ha}$. Treatments did not differ significantly when the 2004 yield was analyzed according to cultivar and aldicarb treatments applied to plots during 2003.

Grain quality. Grain test weight was lower $(P<0.05)$ in aldicarb than in control treatments at both Moro-1 and Moro-2 (data not presented). Grain kernel weight was also lower $(P<0.05)$ in aldicarb than in control treatments at Moro-2 but not Moro-1.

Grain at the Cuthbert farm became shriveled after irrigation was terminated in the
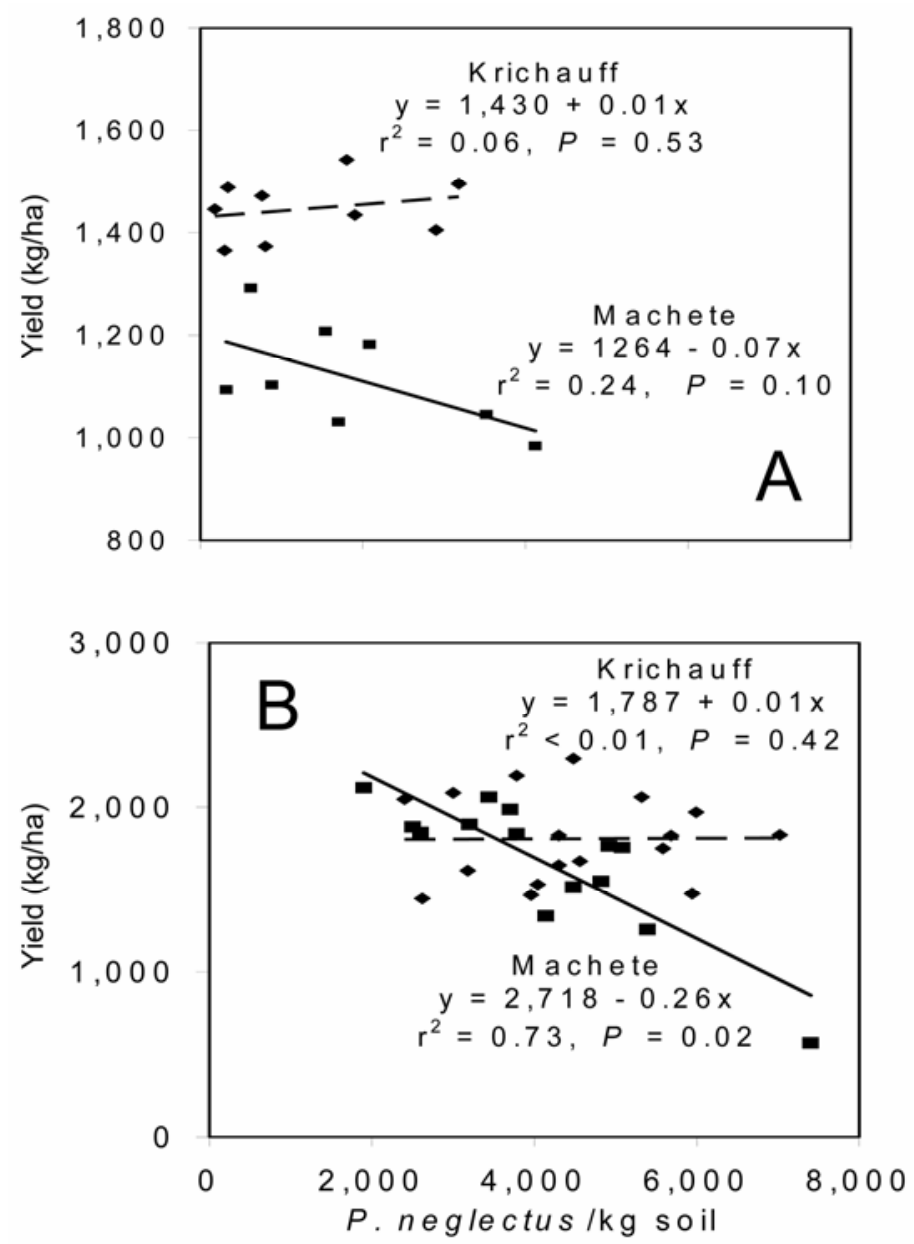

Fig. 1. Relationships between initial population of Pratylenchus neglectus and yield of spring wheat cvs. Krichauff and Machete in control plots (not treated with aldicarb) at the A, Moro-1 and B, Davis-2 experiments during 2003. early soft-dough stage. Aldicarb treatment at the Cuthbert farm led to improvement in test weight $\left(653\right.$ versus $665 \mathrm{~kg} / \mathrm{m}^{3}, \mathrm{LSD}_{0.05}=$ 11) but not kernel weight. At the fully watered Davis-1 experiment, aldicarb treatment improved test weight (805 versus 811 $\left.\mathrm{kg} / \mathrm{m}^{3}, \mathrm{LSD}_{0.05}=3\right)$ and kernel weight $(35$ versus $37 \mathrm{mg} /$ kernel, $\left.\mathrm{LSD}_{0.05}=1\right)$. Results were similar for the Davis-2 experiment, where test weights in aldicarb and control plots were 794 and $786 \mathrm{~kg} / \mathrm{m}^{3}\left(\mathrm{LSD}_{0.05}=4\right)$ and kernel weights were 37 and 34 $\mathrm{mg} /$ kernel $\left(\mathrm{LSD}_{0.05}=2\right)$, respectively.

Associations between $P$. neglectus and grain yield. Significantly negative correlations were common between grain yields and initial populations of $P$. neglectus. The likely bias from aldicarb and cultivar variables was avoided by placing emphasis on control plots for individual cultivars. Under dryland conditions at the Moro-1 experiment, the Pratylenchus population in control plots was negatively correlated with yield (Fig. 1A). As the initial population of $P$. neglectus increased in plots with 0 to 4,000 nematodes $/ \mathrm{kg}$, the yield of Krichauff (moderately resistant and moderately tolerant) was unaffected and yield of Machete (susceptible and intolerant) was reduced $(P=0.10)$ by $22 \%$. Slopes of the regressions for the two cultivars (Fig. 1A) differed significantly $(P<0.05)$. A similar but more statistically significant relationship occurred for these same cultivars at the irrigated Davis-2 experiment, where Krichauff yield was unaffected and yield of Machete declined $(P=0.02)$ by $71 \%$ as the $P$. neglectus population increased in plots with 1,800 to 7,600 nematodes $/ \mathrm{kg}$ (Fig. 1B). Again, the regression slopes for these cultivars differed significantly $(P<0.05)$.

Similar relationships occurred for Frame (moderately susceptible and moderately intolerant to tolerant) and Spear (susceptible and intolerant) at the irrigated Cuthbert (Fig. 2A) and Davis-2 (Fig. 2B) experiments. At the Cuthbert farm, yield of Frame was unaffected and yield of Spear declined $29 \%$ as the preplant $P$. neglectus population increased in plots with 0 to about 6,000 nematodes $/ \mathrm{kg}$. At the Davis-2 experiment, yields of Frame and Spear declined 11 and $36 \%$, respectively, as the $P$. neglectus population increased in plots with 0 to 4,000 nematodes $/ \mathrm{kg}$.

There also were negative correlations between yield and $P$. neglectus density in roots for three experiments. The intolerance of Spear to P. neglectus was particularly evident in aldicarb-treated plots at the Moro-2 experiment (Fig. 3), where yield declined rapidly in plots with greater than 20 P. neglectus/g of fresh root tissue (about 80 P. neglectus/g on an oven-dry basis). Densities of $P$. neglectus in roots of Krichauff at this very dry nonirrigated site were mostly less than 8 per $g$ of fresh root tissue, and were unrelated to yield. Root weights were higher for Krichauff than for 
Spear in this experiment, but grain yields did not differ between cultivars.

During 2004, at the only experiment (Moro-1) replanted to evaluate residual responses of treatments on yield of the locally adapted cultivar Zak, yield was negatively correlated $(P<0.001)$ with initial density of $P$. neglectus in soil (Fig.
4). Yield of Zak declined $16 \%$ as the initial population of $P$. neglectus increased in plots with 0 to 4,000 nematode/ $\mathrm{kg}$ of soil.

Where irrigation was terminated prematurely at the Cuthbert farm during 2003, grain yield was negatively correlated with canopy leaf temperature $\left(P<0.0001, r^{2}=\right.$ $0.46)$. The relationship was weaker but still
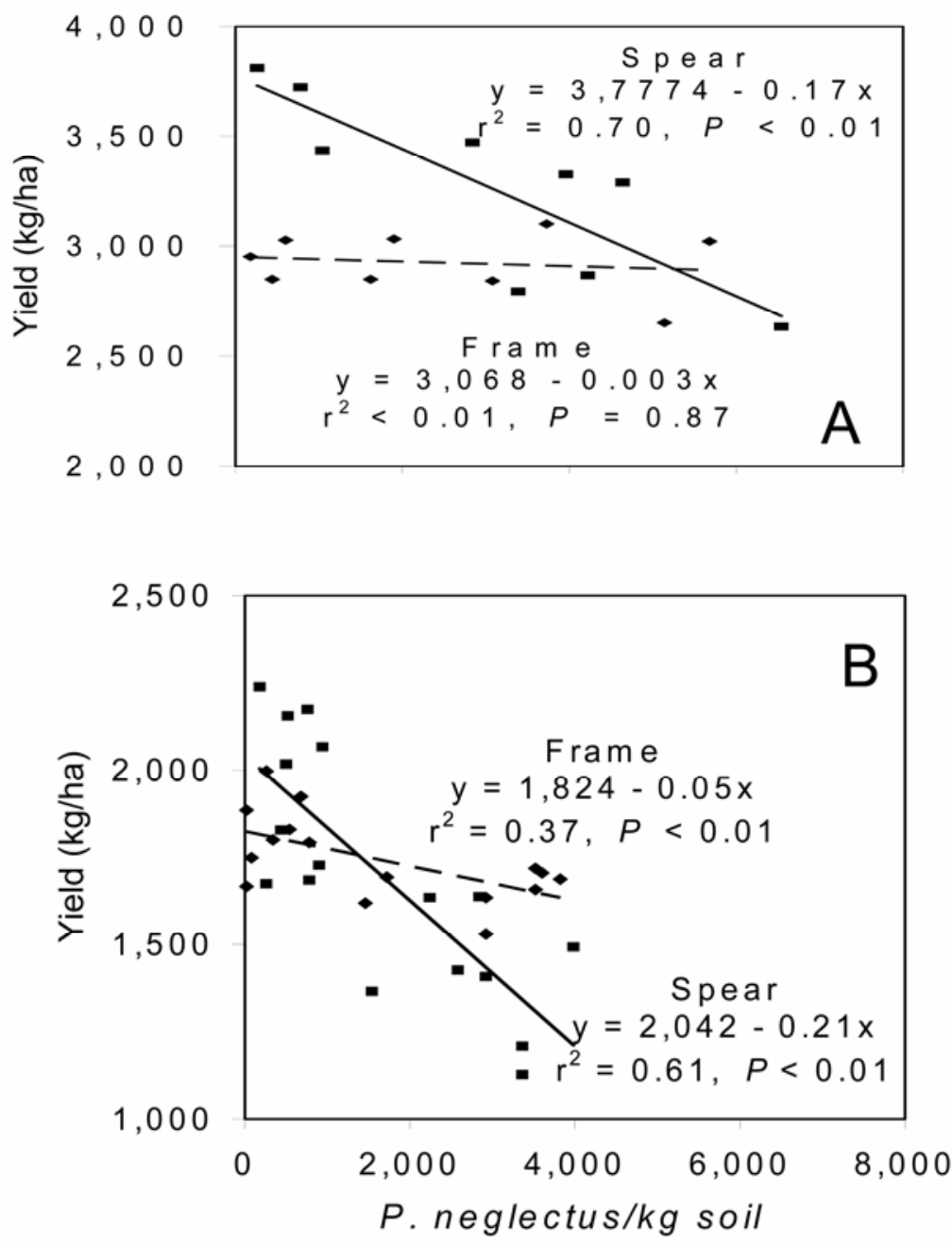

Fig. 2. Relationships between initial population of Pratylenchus neglectus and yield of spring wheat cvs. Frame and Spear in control plots (not treated with aldicarb) at the A, Cuthbert and B, Davis-1 experiments during 2003.

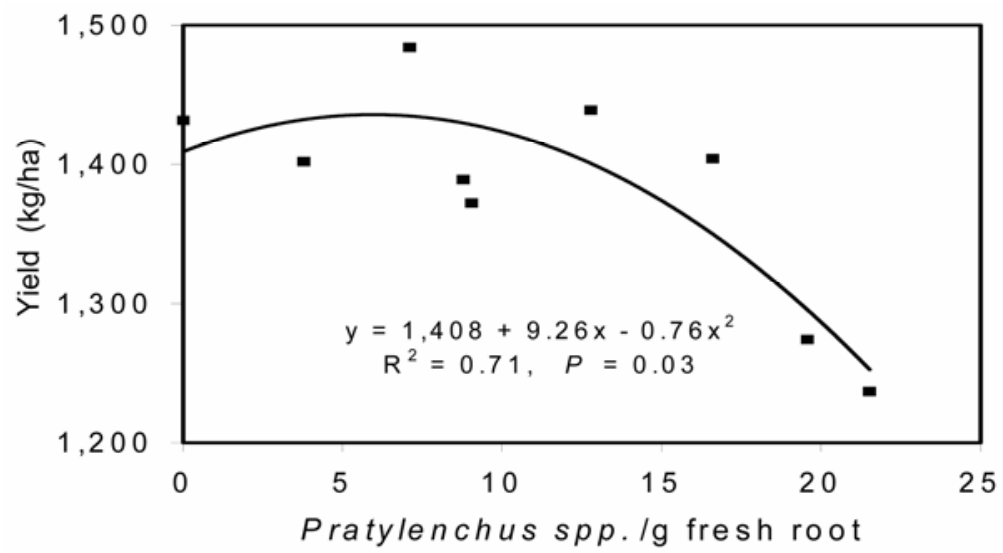

Fig. 3. Relationship between density of Pratylenchus neglectus in roots (fresh-weight basis) and yield of spring wheat cv. Spear in aldicarb-treated soil at the Moro-2 experiment during 2003.

significant at the adequately watered Davis-1 $\left(P=0.02, r^{2}=0.08\right)$ and Davis-2 $\left(P=0.004, r^{2}=0.23\right)$ experiments. At the latter site, density of $P$. neglectus in roots was inversely correlated with test weight $\left(P=0.003, r^{2}=0.24\right)$, tiller height $(P=$ $\left.0.04, r^{2}=0.12\right)$, and canopy temperature $\left(P=0.06, r^{2}=0.10\right)$.

\section{DISCUSSION}

This is the first report that $P$. neglectus causes economic damage to spring wheat in the Pacific Northwest. High populations of $P$. neglectus in soil at planting were correlated with up to $71 \%$ reduction in grain yield. Damage was demonstrated in irrigated as well as dryland fields. Yields of a moderately tolerant cultivar were higher than those of intolerant cultivars in dryland fields, and the density of $P$. neglectus was higher in susceptible than in moderately resistant cultivars. In South Australia and Victoria, wheat yields in dryland fields are also inversely associated with the initial density of $P$. neglectus in soil $(41,44)$. In the current experiments, specific associations between grain yield and initial populations of $P$. neglectus in soil were variable, making it impossible to suggest damage thresholds based on studies reported in this paper. However, it was clear that initial $P$. neglectus populations as low as 2,000 per $\mathrm{kg}$ of soil were capable of limiting grain yield in one dryland (Moro-1; Figs. 1A and 4) and one irrigated (Davis-1; Fig. 2B) experiment. Yield constraints from initial populations as low as 3,000 P. neglectus $/ \mathrm{kg}$ of soil have been reported in Australia (44). Pratylenchus populations exceeding 2,500 per $\mathrm{kg}$ of soil in the surface $20 \mathrm{~cm}$ of the soil profile occur in $20 \%$ of the intensively cropped fields in the Pacific Northwest (34). Populations of Pratylenchus spp. at depths greater than $20 \mathrm{~cm}$ have not been investigated, possibly leading to important underestimations of percentages of fields having high populations (39). It is therefore important to recognize $P$. neglectus as another important constraint to yield in Pacific Northwest fields planted to cereals more frequently than once every 2 years.

Reviews of literature indicate that yield reductions by $P$. thornei are generally greater than by $P$. neglectus $(20,44)$. Yield reductions up to 70 and $85 \%$ were associated with $P$. thornei in Israel and Australia, respectively. Yield reductions associated with $P$. neglectus were generally in the range of 16 to $40 \%$. Yields have been suppressed as much as $74 \%$ in the presence of a mixed population of $P$. thornei and $P$. neglectus (44). P. thornei has been reported to reduce yield of intensively cropped spring wheat by as much as 40 to $60 \%$ in the Pacific Northwest (36). P. neglectus was generally associated with yield reductions of 8 to $36 \%$ for studies reported in this paper, although yield for one intolerant cultivar was suppressed $71 \%$ in a field also 
highly infested with $H$. avenae, Paratylenchus spp., and soilborne root-infecting fungi. The greater damage reported for $P$. thornei than for P. neglectus in the Pacific Northwest appears consistent with reports from other regions.

Accurate identification of Pratylenchus species is important because cultivars of wheat and other field crops differ in resistance and/or tolerance to $P$. neglectus and $P$. thornei $(9,40,44)$. Rotations effective for reducing populations of $P$. thornei may not be effective for reducing populations of $P$. neglectus, and wheat cultivars with tolerance to $P$. thornei may be intolerant to $P$. neglectus. Differentiation between $P$. neglectus and $P$. thornei using standard microscopy can be challenging $(11,14)$. Recent advances in molecular diagnostics $(24,47)$ provide an opportunity to achieve a higher level of precision for identifying Pratylenchus species. The current study quantified the population of Pratylenchus in the traditional manner, by sending samples to a commercial diagnostic laboratory, and then also employing molecular diagnostics to identify and estimate proportions of individual Pratylenchus species in the extracts. Diagnostic services in Australia have advanced to a level permitting the quantification and identification processes to be combined (24), but that level of precision and calibration is not yet available in the Pacific Northwest.

In nonirrigated soil infested with $P$. neglectus, the moderately tolerant cultivar Krichauff yielded more grain than the intolerant cultivars Machete and Spear. These intolerant cultivars also exhibited a lower capacity than Krichauff and another moderately tolerant cultivar, Frame, to maintain optimal yields in plots with higher soil populations of $P$. neglectus at dryland as well as irrigated sites in Oregon. The locally adapted cultivar Zak was shown to be intolerant of $P$. neglectus. While the Australian cultivars served an important need in this research, they are not well adapted to production systems in the Pacific Northwest. Genes for tolerance to $P$. neglectus must be crossed into highyielding, locally adapted spring wheat cultivars intended for planting into annual cereal cropping systems in the Pacific Northwest. Cultivars and lines with levels of tolerance higher than for Krichauff have been identified (44) and should serve as the focus for breeding programs in the Pacific Northwest.

The multiplication factor $(\mathrm{Pf} / \mathrm{Pi})$ for $P$. neglectus in control plots at the irrigated Davis-2 experiment was lower for Krichauff (0.23) than for Machete (0.96). In South Australia, relative Pf/Pi ratings of 0 and 1.71 were reported (40) for Krichauff and Machete, respectively, leading to ranking these cultivars as resistant and susceptible, respectively. For control plots at the Davis-1 experiment, we did not observe a significant difference between multiplication factors for Frame (0.44) and Spear (0.48). Both cultivars are susceptible to $P$. neglectus in Australia, where relative multiplication factors of 1.35 and 1.09 have been reported (40). Demonstrations that Krichauff had a higher level of relative resistance than Frame, Machete, and Spear in the current study is therefore consistent with previous reports for these cultivars and supports the conclusion that it will be possible to reduce $P$. neglectus population densities in soil by growing resistant cultivars. As with tolerance ratings, cultivars and lines with much higher resistance ratings than expressed by Krichauff are now recognized $(6,49)$ and should be utilized in wheat breeding programs in the Pacific Northwest.

Multiplication factors (Pf/Pi) for P. neglectus were higher for two dryland sites than for two irrigated sites. Taylor et al. (40) also reported higher multiplication factors for $P$. neglectus in drier than in wetter regions. Initial populations of $P$. neglectus were higher at the irrigated than at dryland sites in the current study. Higher multiplication rates in soils with lowest initial populations are consistent with previous reports (30) and may have been responsible for the significantly lower multiplication rates in response to aldicarb treatment at the irrigated but not dryland sites in the current study.

Aldicarb typically reduced the density of $P$. neglectus in roots, increased plant height and tiller density, and reduced leaf canopy temperature and variation in tiller height. Also, aldicarb improved grain yield and quality where water was sufficient for plants to respond to protection from nematode damage, but did not improve yields when crops at these very dry locations were not irrigated. Grain quality tended to be reduced by application of aldicarb at the driest sites, presumably by increasing the amount of water extracted from soil by seedlings, thereby creating an earlier or more intense shortage of water late in the growing season. Aldicarb had no effect on growth or yield of spring wheat in an Oregon field where populations of plantparasitic nematodes were very low (36). While aldicarb proved useful for illustrating the negative impact of $P$. neglectus on growth and yield of spring wheat, this nematicide is not registered for this purpose in the United States.

Spring wheat in the Pacific Northwest receives little in-season rainfall, and generally depletes stored water in the soil profile before plant maturity. Plant canopy temperature is directly correlated with water stress in wheat $(8,31)$, and has been used as an indicator of plant stress induced by plant-pathogenic fungi and plantparasitic nematodes (21). Canopy temperature was as much as $4^{\circ} \mathrm{C}$ higher in control than in aldicarb-treated plots, indicating a higher level of plant water stress in soils with high populations of $P$. neglectus. Comparable canopy temperature differentials were detected for spring wheat grown in soils infested with $P$. thornei (36). For both Pratylenchus species, temperature differentials between aldicarb-treated and control plots were higher in magnitude than temperature differentials reported for soils infested with $H$. avenae in France (21). The greater temperature differential in nematode-damaged plants in the Pacific Northwest than in northern Europe was an indication that wheat plants are more sensitive to nematode damage in semiarid regions where stresses from root dysfunction and water depletion are considered to be additive. In studies reported here, populations as low as 20 P. neglectus/g of fresh root tissue (ca. 80 P. neglectus/g of dry tissue) were associated with reduced root weight and grain yield for the intolerant cultivar Spear at one low-rainfall site.

Intolerant plants with roots heavily damaged by $P$. thornei may exhibit stunting, poor vigor, reduced tillering, and pre-

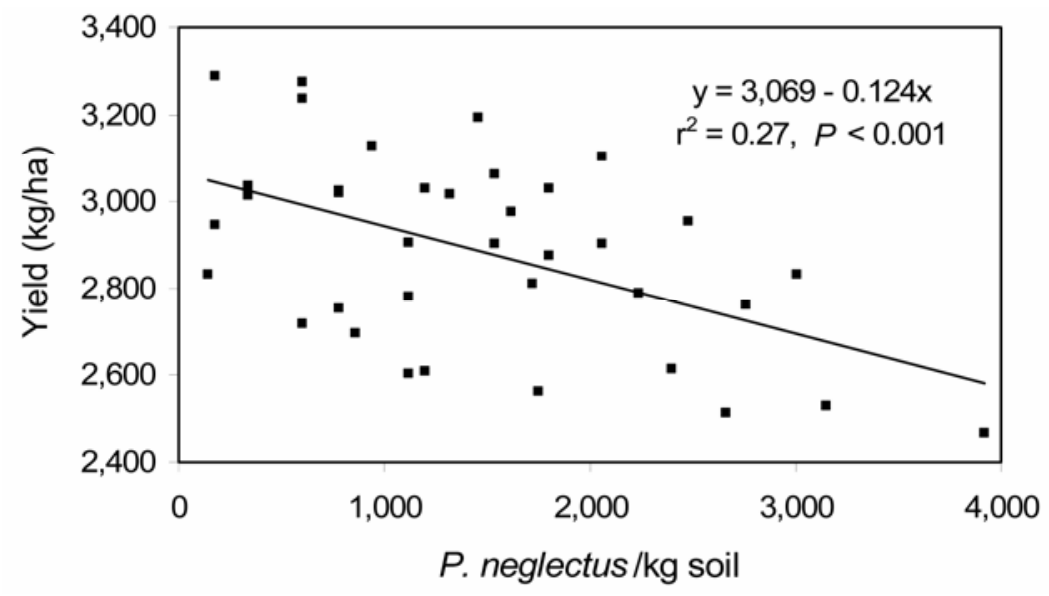

Fig. 4. Relationship between initial density of Pratylenchus neglectus in soil and yield of spring wheat cv. Zak at the Moro-1 experiment during 2004. Zak was planted uniformly over plots in which a gradient in P. neglectus density was created during 2003 by planting plots with spring wheat cvs. Krichauff or Machete, each with or without aldicarb treatment. 
mature wilt at the onset of moisture stress $(7,25,43)$. It is presumed that parasitism of roots by $P$. neglectus causes similar symptoms. However, these foliar symptoms are similar to those caused by other abiotic and biotic stresses and are therefore not diagnostic for invasion of wheat roots by Pratylenchus spp. Without benefit of systematic soil testing for enumeration and identification of plant-parasitic nematodes, the symptoms described above are likely to be ascribed to plant stresses caused by inadequate availability of soil nutrients, impedance to root penetration, low or high temperature, insufficient water for plant growth and maturation, or infection of roots by soilborne plant-pathogenic fungi. The current demonstration that Pratylenchus species are a contributing cause for poor wheat growth and yield in the Pacific Northwest, together with economic constraints to intensive and/or frequent sampling programs to detect plant-parasitic nematode populations in large acreages of dryland field with irregular terrain, indicates that development of resistant and tolerant germ plasm will be the most costeffective strategy for improving wheat yields in fields heavily infested with Pratylenchus species. Since $P$. neglectus and $P$. thornei initially invade roots of resistant as well as susceptible plants, they may cause damage to roots of resistant-intolerant as well as susceptible-intolerant hosts. Genetic tolerance therefore may improve performance of the current crop, and resistance may reduce the magnitude of threat to subsequent crops. Both tolerance and resistance are needed for annual wheat in the Pacific Northwest.

Variability in height of headed tillers was reduced by the aldicarb treatment within experiments, and was considered an important quantitative indicator of relative damage by $P$. neglectus. A similar relationship was reported for P. thornei (36). Variability in head height appears useful for ranking wheat tolerance reactions in fields highly infested with $P$. neglectus and $P$. thornei.

Interactions among nematodes and fungal pathogens are well known $(1,15,38)$. Observations at the Davis farm indicated a negative association between take-all and a browning root-rot complex composed mostly of damage by $P$. neglectus, $R$. solani, and Pythium species. Positive associations also occurred between severity of the root rot complex and initial population of $P$. neglectus and density of $P$. neglectus in roots. Interactions of $R$. solani and $P$. neglectus have been reported for winter wheat (2). The fungal pathogen was considered most important, but $P$. neglectus apparently enhanced the development of root rot. Multiplication rates of $P$. neglectus were amplified when the nematode entered root tissue already breached by the fungal pathogen. However, when $R$. solani and $G$. graminis var. tritici (take-all) both occupied the same root tissue, the combination of fungal pathogens caused a strong reduction in nematode reproduction (2). This apparently occurred because the roots were so heavily damaged by the fungi that there were few healthy cells available for nematode feeding and multiplication. Likewise, the density of $P$. neglectus in wheat roots has been amplified by the presence of $R$. solani, Bipolaris sorokiniana, Pythium irregulare, G. graminis var. tritici, Microdochium bolleyi, or Fusarium equiseti (38). A combination of $R$. solani and G. graminis var. tritici reduced multiplication rates for $P$. neglectus. Severity of root rot was increased by various combinations of $P$. neglectus and fungal pathogens. A similar inverse relationship has also been reported for $P$. neglectus and $H$. avenae (18). The first species to colonize root tissue caused a subsequent reduction in reproductive capacity for the laterarriving parasite. However, a negative interaction between $P$. neglectus and $H$. avenae was not detected in the present study. Interactions among plant-parasitic nematodes and soilborne fungal pathogens are clearly complex and must be considered as fully as possible when interpreting results of field trials.

Many growers who adopt direct-drill systems in the Pacific Northwest plant cereals annually because rotational opportunities are limited for economic and climatic reasons. In Australian soils heavily infested with $P$. neglectus, growers attempt to minimize damage by rotating crops. Although crop rotation is a preferred management practice (27), limiting damage by $P$. neglectus through rotation in the Pacific Northwest will be challenging because this species infests a wide range of field crop species (40) and broadleaf and grass weeds $(45,46)$. In general, most commercial wheat and chickpea (Cicer arietinum L.) cultivars are considered good hosts for multiplication of $P$. neglectus. Poor hosts include field pea (Pisum sativum L.) and triticale ( $X$ Triticosecale Wittmack). Acreages of field pea and triticale are currently very limited in the Pacific Northwest small grain production region. Efforts to expand numbers and types of profitable crops for rotations have not been successful in the Pacific Northwest. Under current economic conditions, significant progress in limiting damage from $P$. neglectus is therefore likely to occur through wheat breeding rather than from further efforts to develop profitable crop rotations. Fortunately, much progress and promise exists for breeding wheat cultivars with sufficiently high tolerance and/or resistance to stabilize yields and reduce the multiplication efficiency for $P$. neglectus $(6,49$, 50,51).

Other plant-parasitic nematode genera and species were detected in soil during the course of these experiments. Populations of Tylenchorhynchus, Geocenamus,
Meloidogyne, and Criconemoides were each low and unlikely to have imposed any significant growth constraint on spring wheat $(17,23,29)$. A high population of Paratylenchus was present at the two irrigated farms, and the impact of Paratylenchus on wheat growth has not been determined. High populations of Paratylenchus in some Pacific Northwest field crops were previously reported $(13,34)$.

Populations of $H$. avenae were high in experiments at the Davis farm. Grain yield for control plots (not treated with aldicarb) in the Davis-1 experiment was negatively $(P<0.05)$ associated with the initial population of P. neglectus (Fig. 2B). However, Frame is classified as tolerant to moderately tolerant to the Australian population of $H$. avenae as well as $P$. neglectus (48), and Spear is classified as intolerant to moderately intolerant to both plantparasitic species in Australia. The current study generally found that tolerance reactions for Australian wheat cultivars challenged with strains of $P$. neglectus in Oregon were comparable to published tolerance ratings for these cultivars in Australia. In contrast, Frame and other cultivars with enhanced tolerance to the Australian population of $H$. avenae were reported to be no better than intolerant cultivars when grown in soils infested with the Oregon population of $H$. avenae (37). In affiliated studies, Frame and Spear were considered equally intolerant of the $H$. avenae population at the Davis farm (37). In the present experiment, significant negative correlations occurred between the initial $P$. neglectus population and yield for both cultivars. It therefore appears that the previously reported negative association between four spring wheat cultivars and the population of $H$. avenae at the Davis farm (37) represented a general response to all cultivars in that experiment, and that grain yields for Frame and Spear were instead more closely associated with damage from the $P$. neglectus population than the $H$. avenae population. This conclusion is supported by associated results reported from the Davis farm in this paper, namely that, in addition to grain yield, there also were significant $(P<0.05)$ negative correlations between $P$. neglectus populations in roots and leaf canopy temperature, tiller height, and test weight. However, it was also apparent that the $71 \%$ yield suppression for an intolerant cultivar in the presence of $H$. avenae, Paratylenchus spp., $P$. neglectus, and fungal pathogens at the Davis-2 experiment greatly exceeded the general range (8 to $36 \%$ ) for yield suppression by $P$. neglectus alone.

In summary, plots with higher populations of $P$. neglectus in soil were correlated with reduction in spring wheat yield in the Pacific Northwest. Damage by P. neglectus was demonstrated in irrigated and dryland fields. Invasion of spring wheat by $P$. neglectus also increased late-season stress 
(higher canopy temperature) and reduced plant biomass production (plant height, root weight, and tillering) and grain quality (test weight and kernel weight). As with $P$. thornei (36), P. neglectus must be included on the lists of pathogens known to limit productivity of spring wheat in annualcrop systems in the Pacific Northwest $(26,32)$. This is important because economics and air and soil quality issues are causing increasing numbers of growers to plant fields annually to spring cereals rather than to the traditional 2-year winter wheat-summer fallow rotation. Pratylenchus species pose a higher level of risk to annual cereals than to wheat rotated with summer fallow (34).

\section{ACKNOWLEDGMENTS}

We thank Vivien Vanstone (Western Australia Department of Agriculture, Perth) and Sharyn Taylor (South Australian Research and Development Institute, Adelaide) for providing guidance on methods and wheat cultivars for this research, Hugh Wallwork (SARDI, Adelaide, Australia) for providing wheat germ plasm, and Stephen Machado (Oregon State University) for providing thermal imaging equipment. We thank Erling Jacobsen (Oregon State University) and John Cuthbert and Roger Davis (wheat producers) for hosting field experiments, and Harry Kreeft (Western Laboratories, Parma, ID) and Kathy Ophel-Keller (Root Disease Testing Service, Adelaide, South Australia) for nematode quantification and identification services. We thank John Collins, Jonathan Jackson, Joanna Skirvin, and Tina Zeckman for technical assistance. This research was funded by an OSU subcontract to the USDA-Agricultural Research Service, SCA\#58-5348-9-100, "Control of Root Diseases of Wheat and Barley".

\section{LITERATURE CITED}

1. Abawi, G. S., and Chen, J. 1998. Concomitant pathogen and pest interactions. Pages 135-158 in: Plant Nematode Interactions. Agron. No. 36. K. R. Barker, G. A. Pederson, and G. L. Windham, eds. American Society of Agronomy, Madison, WI.

2. Benedict, W. G., and Mountain, W. B. 1956. Studies on the etiology of a root rot of winter wheat in Southern Ontario. Can. J. Bot. 34:159-174.

3. Clewett, T. G., Thompson, J. P., and Fiske, M. L. 1993. Crop rotation to control Pratylenchus thornei. Proc. Pratylenchus Workshop, Bien. Australas. Plant Pathol. Conf., 9th. Hobart, Tasmania.

4. Cook, R. J. 2001. Retooling Agriculture: A report on direct-seed cropping systems research in the Pacific Northwest. Washington State Univ. PNW Ext. Publ. 553.

5. Cook, R. J., and Veseth, R. J. 1991. Wheat Health Management. American Phytopathological Society, St. Paul, MN.

6. Das, R. K., Vanstone, V. A., Russ, M. H., and Rathjen, A. J. 2004. Development of bread and durum wheats for resistance to Pratylenchus neglectus. Pages 207-208 in: Proc. Australas. Soilborne Dis. Sympos. 3rd. K. Ophel-Keller and B. Hall, eds. Rowland Flat, South Australia.

7. Doyle, A. D., McLeod, R. W., Wong, P. T. W., Hetherington, S. E., and Southwell, R. J. 1987. Evidence for the involvement of the root lesion nematode Pratylenchus thornei in wheat yield decline in northern New South Wales. Aust. J. Exp. Agric. 27:563-570.

8. Ehrler, W. L., Idso, S. B., Jackson, R. D., and Reginato, R. J. 1978. Wheat canopy temperature: Relation to plant water potential. Agron. J. 70:251-256.
9. Farsi, M., Vanstone, V. A., Fisher, J. M., and Rathjen, A. J. 1995. Genetic variation in resistance to Pratylenchus neglectus in wheat and triticales. Aust. J. Exp. Agric. 35:597-602.

10. Ferris, H., Carlson, H. L., and Westerdahl, B. B. 1994. Nematode population changes under crop rotation sequences: Consequences for potato production. Agron. J. 86:340-348

11. Filho, A. C. C., and Huang, C. S. 1989. Description of Pratylenchus pseudofallax n.sp. with a key to species of the genus Pratylenchus Filipjev, 1936 (Nematoda: Pratylenchidae). Rev. Nématol. 12:7-15.

12. Gair, R., Mathias, P. L., and Harvey, P. N. 1969. Studies of cereal nematode populations and cereal yields under continuous or intensive culture [Heterodera avenae, Pratylenchus neglectus, Trichodorus primitivus]. Ann. Appl. Biol. 63:503-512

13. Hafez, S. I., Golden, A. M., Rashid, F., and Handoo, Z. 1992. Plant-parasitic nematodes associated with crops in Idaho and eastern Oregon. Nematropica 22:193-204.

14. Handoo, Z. A., and Golden, A. M. 1989. A key and diagnostic compendium to the species of the genus Pratylenchus Filipjev, 1936 (lesion nematodes). J. Nematol. 21:202-218.

15. Hussey, R. S., and McGuire, J. M. 1987. Interaction with other organisms. Pages 293-328 in: Principles and Practice of Nematode Control in Crops. R. H. Brown and B. R. Kerry, eds. Academic Press, Sydney, Australia.

16. Ingham, R. E. 1994. Nematodes. Pages 459490 in: Methods of Soil Analysis, Part 2. Microbiological and Biochemical Properties. R. W. Weaver, ed. American Society of Agronomy, Madison, WI.

17. Langdon, K. R., Struble, F. B., and Young, H. C., Jr. 1961. Stunt of small grains, a new disease caused by the nematode Tylenchorhynchus brevidens. Plant Dis. Rep. 45:248-352.

18. Lasserre, F., Rivoal, R., and Cook, R. 1994. Interactions between Heterodera and Pratylenchus neglectus on wheat. J. Nematol. 26:336344.

19. Mojtahedi, H., Santo, G. S., and Kraft, J. M. 1992. Pratylenchus neglectus on dryland wheat in Washington. Plant Dis. 76:323.

20. Nicol, J., Rivoal, R., Taylor, S., and Zaharieva, M. 2003. Global importance of cyst (Heterodera spp.) and lesion nematodes (Pratylenchus spp.) on cereals: Yield loss, population dynamics, use of host resistance and integration of molecular tools. Nematol. Monogr. Perspectives 2:1-19.

21. Nicolas, H., Rivoal, R., Duchesne, J., and Lili, Z. 1991. Detection of Heterodera avenae infestations on winter wheat by radiothermometry. Rev. Nématol. 14:285-290.

22. Nombela, G., Navas, A., and Bello, A. 1998. Effects of crop rotations of cereals with vetch and fallow on soil nematofauna in central Spain. Nematologica 44:63-80.

23. Nyczepir, A. P., Inserra, R. N., O'Bannon, J. H., and Santo, G. S. 1984. Influence of Meloidogyne chitwoodi and Meloidogyne hapla on wheat growth. J. Nematol. 16:162-165.

24. Ophel-Keller, K., and McKay, A. 2001. Root disease testing service: Delivery and commercialisation. Pages 17-18 in: Proc. Australas. Soilborne Dis. Sympos. 2nd. I. J. Porter, ed. Lorne, Victoria.

25. Orion, D., Amir, J., and Kirkun, J. 1984. Field observations on Pratylenchus thornei and its effects on wheat under arid conditions. Rev. Nématol. 7:341-345.

26. Paulitz, T., Smiley, R., and Cook, R. J. 2002. Insights into the prevalence and management of soilborne cereal pathogens under direct seeding in the Pacific Northwest U.S.A. Can. J. Plant Pathol. 24:416-428.

27. Riley, I. T., and Kelly, S. J. 2002. Endoparasitic nematodes in cropping soils of Western Australia. Aust. J. Exp. Agric. 42:49-56.
28. Roberts, P. A. 2002. Concepts and consequences of resistance. Pages 23-41 in: Plant Resistance to Parasitic Nematodes. J. L. Starr, R. Cook, and J. Bridge, eds. CAB International, Wallingford, UK.

29. Santo, G. S., and O'Bannon, J. H. 1981. Pathogenicity of the Columbia root-knot nematode (Meloidogyne chitwoodi) on wheat, corn, oat, and barley in the Pacific Northwest. J. Nematol. 13:548-550.

30. Seinhorst, J. W. 1966. The relationships between population increase and population density in plant-parasitic nematodes. I. Introduction and migratory nematodes. Nematologica 12:157-169.

31. Siddique, M. R. B., Hamid, A., and Islam, M. S. 2000. Drought stress effects on water relations of wheat. Bot. Bull. Acad. Sin. 41:35-39.

32. Smiley, R. W. 1996. Diseases of wheat and barley in conservation cropping systems of the semiarid Pacific Northwest. Am. J. Altern. Agric. 11:95-103.

33. Smiley, R. W., Collins, H. P., and Rasmussen, P. E. 1996. Diseases of wheat in long-term agronomic experiments at Pendleton, Oregon. Plant Dis. 80:813-820.

34. Smiley, R. W., Merrifield, K., Patterson, L.-M., Whittaker, R. G., Gourlie, J. A., and Easley, S. A. 2004. Nematodes in dryland field crops in the semiarid Pacific Northwest United States. J. Nematol. 36:54-68.

35. Smiley, R., Siemens, M., Gohlke, T., and Poore, J. 2005. Small grain acreage and management trends for eastern Oregon and Washington. Oregon Agric. Exp. Stn. Spec. Rep. 1061:30-50.

36. Smiley, R. W., Whittaker, R. G., Gourlie, J. A and Easley, S. A. Pratylenchus thornei associated with reduced wheat yield in Oregon. J. Nematol. 37:45-54.

37. Smiley, R. W., Whittaker, R. G., Gourlie, J. A., Easley, S. A., and Ingham, R. E. Heterodera avenae density influences wheat yield in Oregon. J. Nematol. In press.

38. Taheri, A., Hollamby, G. J., Vanstone, V. A., and Neate, S. M. 1994. Interaction between root lesion nematode, Pratylenchus neglectus (Rensch 1924) Chitwood and Oteifa 1952, and root rotting fungi of wheat. N.Z. J. Crop Hortic. Sci. 22:181-185.

39. Taylor, S. P., and Evans, M. L. 1998. Vertica and horizontal distribution of and soil sampling for root lesion nematodes (Pratylenchus neglectus and $P$. thornei) in South Australia. Australas. Plant Pathol. 27:90-96.

40. Taylor, S. P., Hollaway, G. J., and Hunt, C. H. 2000. Effect of field crops on population densities of Pratylenchus neglectus and P. thornei in southeastern Australia. Part 1: P. neglectus. J. Nematol. 32:591-599.

41. Taylor, S. P., Vanstone, V. A., Ware, A. H., McKay, A. C., Szot, D., and Russ, M. H. 1999. Measuring yield loss in cereals caused by root lesion nematodes (Pratylenchus neglectus and P. thornei) with and without nematicides. Aust. J. Agric. Res. 50:617-622.

42. Thompson, J. P., and Clewett, T. G. 2004. Soil fumigation to assess the effects of root-lesion nematode (Pratylenchus thornei) on wheat yield. Pages 188-189 in: K. M. Ophel-Keller and B. H. Hall, eds. Proc. Australas. Soilborne Dis. Sympos. 3rd. Adelaide, Australia

43. Van Gundy, S. D., Perez, B. J. G., Stolzy, L. H., and Thomason, I. J. 1974. A pest management approach to the control of Pratylenchus thornei on wheat in Mexico. J. Nematol. 6:107-116.

44. Vanstone, V. A., Rathjen, A. J., Ware, A. H., and Wheeler, R. D. 1998. Relationship between root lesion nematodes (Pratylenchus neglectus and $P$. thornei) and performance of wheat varieties. Aust. J. Exp. Agric. 38:181-189.

45. Vanstone, V. A., and Russ, M. H. 2001. Ability of weeds to host the root lesion nematodes 
Pratylenchus neglectus and $P$. thornei. I. Grass weeds. Australas. Plant Pathol. 30:245-250.

46. Vanstone, V. A., and Russ, M. H. 2001. Ability of weeds to host the root lesion nematodes Pratylenchus neglectus and P. thornei. II. Broad-leaf weeds. Australas. Plant Pathol. 30:251-258.

47. Waeyenberge, L., Ryss, A., Moens, M., Pinochet, J., and Vrain, T. C. 2000. Molecular characterization of 18 Pratylenchus species using rDNA restriction fragment length polymorphism. Nematology 2:135-142.
48. Wheeler, R., and Wurst, M. 2003. Wheat. Pages 45-54 in: Crop Harvest Report: 20022003. D. Lewis and R. Wheeler, eds. Primary Industries and Resources South Australia, Unley, South Australia.

49. Williams, K. J., Taylor, S. P., Bogacki, P., Pallotta, M., Bariana, H. S., and Wallwork, H. 2002. Mapping of the root lesion nematode (Pratylenchus neglectus) resistance gene Rlnn1 in wheat. Theor. Appl. Genet. 104:874-879.

50. Zwart, R. S., Thompson, J. P., Williamson, P. M., and Seymour, N. P. 2004. Elite sources of resistance in wheat to root-lesion nematode (Pratylenchus thornei and Pratylenchus neglectus) and yellow spot (Pyrenophora triticirepentis). Pages 220-221 in: Proc. Australas. Soilborne Dis. Sympos. 3rd. K. Ophel-Keller and B. Hall, eds. Rowland Flat, South Australia.

51. Zwart, R. S., Thompson, J. P., and Godwin, I. D. 2005. Identification of quantitative trait loci for resistance to two species of root-lesion nematode (Pratylenchus thornei and P. neglectus) in wheat. Aust. J. Agric. Res. 56:345-352. 